Portland State University

PDXScholar

$11-4-1994$

\title{
A Comparison of Neutrophil Migration in the Mouse in Response to Infection with Three Species of Trichinella
}

Jon Darin Prulhiere

Portland State University

Follow this and additional works at: https://pdxscholar.library.pdx.edu/open_access_etds

Part of the Biology Commons

Let us know how access to this document benefits you.

\section{Recommended Citation}

Prulhiere, Jon Darin, "A Comparison of Neutrophil Migration in the Mouse in Response to Infection with Three Species of Trichinella" (1994). Dissertations and Theses. Paper 4791.

https://doi.org/10.15760/etd.6675

This Thesis is brought to you for free and open access. It has been accepted for inclusion in Dissertations and Theses by an authorized administrator of PDXScholar. Please contact us if we can make this document more accessible: pdxscholar@pdx.edu. 


\section{THESIS APPROVAL}

The abstract and thesis of Jon Darin Prulhiere for the Master of Science in Biology were presented November 4, 1994, and accepted by the thesis committee and the department.

COMMITTEE APPROVALS:

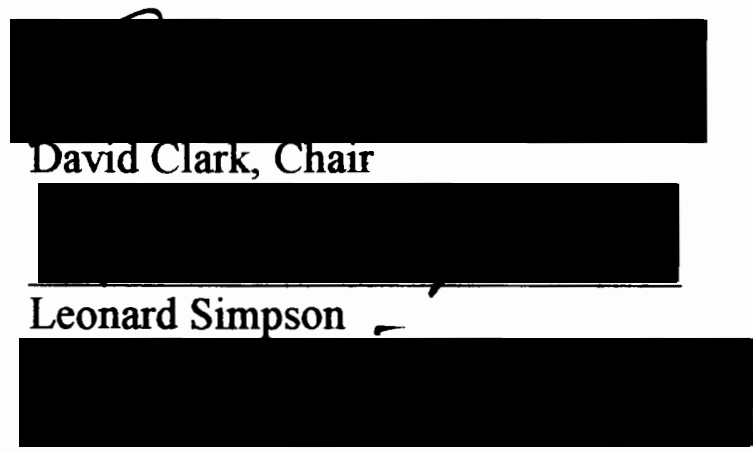

Robert Millette

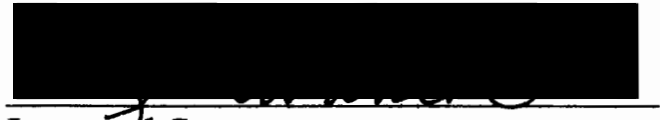

Leonard Swanson

Office of Graduate Studies Representative

DEPARTMENT APPROVAL:

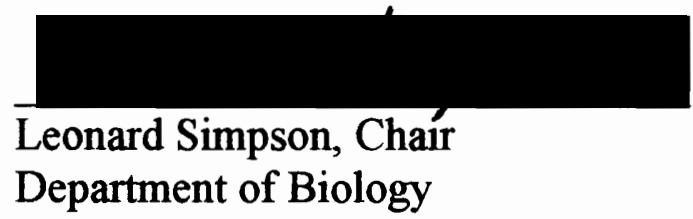

$* * * * * * * * * * * * * * * * * * * * * * * * * * * * * * * * * * * * * * * * * * * * * * * * * * * * * * * * * * * * * * * * * * *$

ACCEPTED FOR PORTLAND STATE UNIVERSITY BY THE LIBRARY

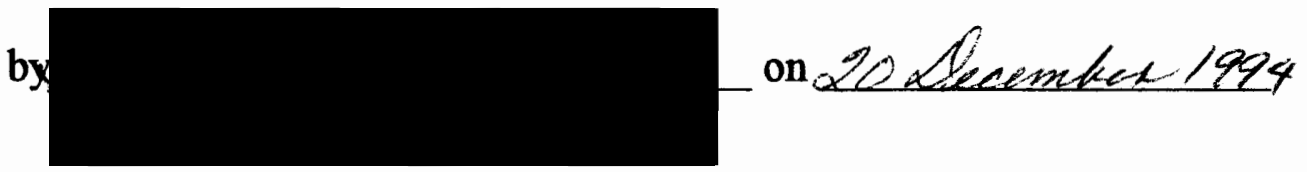




\begin{abstract}
An abstract of the thesis of Jon Darin Prulhiere for the Master of Science in Biology presented November 4, 1994.
\end{abstract}

Title: A Comparison of Neutrophil Migration in the Mouse in Response to Infection with Three Species of Trichinella.

The Genus Trichinella is currently thought to consist of 8 seperate species. Several methods have been used to help differentiate these. In this study the ability of three of these species, $T$. spiralis, $T$. pseudospiralis, and $T$. sp. 3 to idependantly infect MRL+ mice was compared at 5,7,11,18 and 20 days post infection (dpi) with the hope of discovering new distinguishing characteristics. Of interest was the development of inflammation through the accumulation of neutrophils associated with larvae of Trichinella in mouse skeletal muscle. This was evaluated with routine histological stains, endogenous peroxidase staining and immunohistochemical staining specific for neutrophil myeloperoxidase. The inflammatory response in skeletal muscle varied considerably among these three species with neutrophil accumulation being very heavy in the later stages of $T$. spiralis infection, mild in T.sp. 3 and virtually nonexistant in T. pseudospiralis infections. Also, the appearance of neutrophils was closely correlated with the development of a nurse cell or cyst in the larvae that develop these structures. In T. pseudospiralis where cyst formation is absent, there consistently was a lesser degree of inflammation. These results suggest a possible role of neutrophils involved in inflammation or the process of inflammation itself in the production of nurse cell formation as well as confirming previously described antiinflammatory capabilities of T. sp. 3 and T. pseudospiralis. 
A Comparison of Neutrophil Migration in the Mouse in Response to Infection with Three Species of Trichinella

by

Jon Darin Prulhiere

A thesis submitted in partial fulfillment of the requirements for the degree of

MASTER OF SCIENCE

in

BIOLOGY

Portland State University

1994 


\section{TABLE OF CONTENTS}

ACKNOWLEDGMENTS

LIST OF TABLES iv

LIST OF FIGURES $\quad$ v

INTRODUCTION 1

MATERIALS AND METHODS $\quad 4$

Experimental Hosts $\quad 4$

$\begin{array}{ll}\text { Parasites } & 4\end{array}$

Infection of Experimental Hosts 4

Tissue Collection, Fixation, and Processing 4

Detection of Endogenous Peroxidase Activity 6

$\begin{array}{ll}\text { Immunohistochemical Staining } & 8\end{array}$

$\begin{array}{ll}\text { Microscopy } & 9\end{array}$

$\begin{array}{ll}\text { RESULTS } & 14\end{array}$

Histological Evaluation of Hematoxylin and Eosin Stains $\quad 14$

$\begin{array}{ll}\text { Endogenous Peroxidase Activity } & 17\end{array}$

Immunohistochemical Staining for Myeloperoxidase $\quad 20$

DISCUSSION 25

$\begin{array}{lr}\text { LITERATURE CITED } & 29\end{array}$ 


\section{Acknowledgements}

I would like to thank Dr. David Clark, Dr. Jay Beckstead and Dr. Anthony D'Agostino for their advice and expertise. Also I would like to thank Don Andersen, supervisor of the OHSU immunohistochemistry lab for his generosity with reagents and equipment that made this project possible 
LIST OF TABLES

TABLE

1. Immunohistochemical staining protocol

2. Immunohistochemical staining results
PAGE

11

21 


\section{LIST OF FIGURES}

1. Peroxidase use by granulocytes 7

2. Automated immunohistochemistry slides 10

3. Morphological changes in cell in early stage of infection 15

4. Normal mouse tissue 15

5. T. spiralis tissue 11 days post infection $(\mathrm{H}+\mathrm{E}) \quad 16$

6. T. pseudospiralis tissue 11 days post infection $(\mathrm{H}+\mathrm{E})$

7. T. spiralis tissue 20 days post infection $(\mathrm{H}+\mathrm{E}) \quad 18$

8. T. pseudospiralis tissue 20 days post infection $(\mathrm{H}+\mathrm{E}) \quad 18$

9. Myeloperoxidase stained T. sp. 3 tissue 19

10. Myeloperoxidase stained T. spiralis tissue 22

11. Myeloperoxidase stained $T$. spiralis tissue 23

12. Myeloperoxidase stained T. spiralis tissue 23

13. Myeloperoxidase stained T. pseudospiralis tissue 24

14. Myeloperoxidase stained T. sp. 3 tissue 24 


\section{INTRODUCTION}

During the past thirty years considerable effort has been spent directed toward a better understanding of the systematics of the genus Trichinella in which a variety of techniques have been used. Some of the more common of these have been reproductive capacity index (Dick and Chadee, 1981; Murrell et al.,1985; Dame et al., 1987), the resistance of muscle larvae to low temperatures (Boev et al., 1989; Dick and Chadee, 1981; Pozio et al., 1989), host virulence (Kozar and Kozar, 1965; Dick and Chadee, 1981; Leiby and Bacha, 1987), the intestinal distribution of adults and the duration of the intestinal stage (Chadee et al., 1983; Leiby and Bacha, 1987), production of newborn larvae in vitro by female worms (Dick and Chadee, 1983), and sensitivity to drug treatments (Chadee et al., 1983). The interpretation of the combined efforts suggests the need for speciation within the genus Trichinella.

Recently, two groups reported additional evidence suggesting that Trichinella is composed of at least 8 distinct species (La Rosa et al., 1992; Pozio et al., 1992). Using allozyme analysis, La Rosa examined 27 enzymes from 152 Trichinella isolates. This revealed the presense of 8 distinct gene pools, T1-T8. Four of these gene pools represented previously described species: Trichinella spiralis sensu stricto (T1), Trichinella nativa (T2), Trichinella nelsoni (T7), and Trichinella psuedospiralis (T4). The other 4, consiting of $\mathrm{T} 3, \mathrm{~T} 5, \mathrm{~T} 6$, and $\mathrm{T} 8$, were distinct from previously described species.

Pozio et al. (1992) compared isolates from 5 continents and various host species for 7 biological characteristics : newborn larvae produced per female worm at 3 distict time periods, host muscle nurse cell development time, reproductive capacity index $(\mathrm{RCI})$ in rats and chickens and resistance of muscle larvae to freezing and the environmental characteristics of the location of each isolate 
during the months of January and July. These results, in agreement with those of La Rosa (1992), provided additional support that Trichinella should be speciated into at least 8 distinct species.

The results of previous workers show the excellent effort being made to understand this fascinating parasite and its origins. Further, another interesting characteristic of Trichinella, the ability to modify the chemotactic response of mammals to cellular injury, may offer additional insight regarding the questions surrounding the speciation of the genus.

In 1970 a group of Russian investigators observed that skin grafts transplanted to mice infected with Trichinella spiralis survived approximately twice as long as those in noninfected mice (Svet-Moldavsky et. al., 1970). Following this observation they suggested that the parasite might be secreting a component that suppressed the hosts immune system. Until this time, it was previously thought that parasites such as Trichinella managed to survive in immunocompetant hosts by the process of encapsulating themselves in impermeable barriers (i.e the nurse cell, Despommier (1990) )or by expressing surface antigens which may disguise the nematode as host. The suggestion of a secreted factor capable of modifying the hosts immune response was truly perceptive and it continues to be the subject of research to this day.

In 1990, Bruschi et al. examined the sera of patients infected with Trichinella during a trichinellosis outbreak in Northern Italy in 1986. The parasite was identified isoenzymatically as Trichinella $s p$. 3. Studies performed on leukocyte chemotaxis and phagocyotosis indicated that the sera from $T . s p .3$ infected humans inhibited both chemotaxic and phagocytic responses of leukocytes. However, the source and nature of the factor were not identified. 
Infection by Trichinella pseudospiralis in the mouse has been shown to be accompanied by much lower levels of enteritis and myositis than those seen in mice infected with Trichinella spiralis (Stewart et al., 1985). Stewart et. al. (1989) also showed this to be true for Trichinella spiralis in the Chinese hamster, a species known to be highly resistant to Trichinella infection. Larsen et. al. (1991) investigated the infectivity of Trichinella spiralis in Chinese hamsters concurrently infected with Trichinella pseudospiralis. The double species infection appeared to be more severe than in hamsters infected with either Trichinella pseudospiralis or Trichinella spiralis alone. It was also shown that during the first days of infection enteritis in the hamster small intestine, measured by myeloperoxidase activity of small intestine homogenate containing larvae, and myositis in the diaphram were significantly lower in animals infected with Trichinella pseudospiralis alone than in concurrently infected hamsters or those infected only with Trichinella spiralis.

The variation in chemotactic response and localization of inflammatory cells representing inflammatrion to Trichinella infections observed by these authors led us to further examine the myositis in mice induced by three species; Trichinella spiralis, Trichinella pseudospiralis and Trichinella sp. 3. It was thought that variations in the inflammatory response, specifically neutrophil migration and deposition, in the early stages of muscle infection induced by each of these species might suggest possible physiological effects upon this inflammatory response of mice. To investigate this we examined the inflammatory presense of neutrophil localization associated with the muscle phase of larval Trichinella in MRL ++ mice. This included examination of neutrophil migration and deposition at five different time periods during the first 20 dpi histologically, immunohistochemically and enzymatically to identify any defining characteristics. 


\section{MATERIALS AND METHODS}

Experimental Hosts

Male MRL++ mice, originally obtained from Oregon Health Sciences

University, Portland, OR., were 4-5 weeks old when used as experimental hosts. Animals were maintained on a $12 \mathrm{~h}$ light/ $12 \mathrm{~h}$ dark cycle and provided with water and commercial rodent chow ad libitum.

\section{Parasites}

Indiana Bore strain of $T$. spiralis was obtained from Dr. Green, University of Missouri, Columbia. T. pseudospiralis and T. sp.3 were obtained from H. Ray Gambel, USDA, Beltsville, Md. All three species were maintained by passage in rats or mice.

\section{Infection of Experimental Hosts}

Mice were infected orally with tissue containing approximately 30 larvae from either T. spiralis, T. pseudospiralis, or T. sp. 3. Infected tissue was obtained by removing the diaphram of previously infected MRL ++ mice. These were examined under a dissecting microscope and divided into small pieces containing the appropriate number of larvae. Experimental hosts were then infected by using blunt forceps to place the small pieces of infected muscle onto the tongue of the host. Following feeding, each mouse was observed for at least one minute to ensure that the tissue had been swallowed, then returned to the $12 \mathrm{~h}$ light/12h dark cycle with food ad libitium. 
Tissue Collection, Fixation, and Processing

The diaphram muscle was collected from one mouse of each infection type at $5,7,11,18$, and 20 dpi. Mice were killed using cervical dislocation and the diaphram was removed immediately and placed onto a glass slide containing 1-2 drops of Zinc Formalin (Anatech Labs, CA.). The diaphram was then spread out evenly and a second slide was placed on top of it. . The tissue, held flat in between the two glass slides, was then placed into a $50 \mathrm{ml}$ polypropylene centrifuge tube containing enough Zinc Formalin to cover the entire tissue. The capillary action of the paired slides allowed for sufficent exposure of the tissue to the fixative. The tissue was fixed in this manner for 24 to 48 hours.

This method allowed for fixation of the very thin diaphram that left the tissue almost completely flat. Following fixation the tissue was processed for paraffin embedding through a graded series of alcohols, xylene and paraffin as follows : $70 \%$ EtOH 2X, 1 hour each ; 95\% EtOH 2X, 1 hour each ; 100\% Isopropanol 2X, 1 hour each ; Xylene $2 \mathrm{X}, 1 / 2$ hour each ; and $58^{\circ} \mathrm{C}$ paraffin $2 \mathrm{X}, 15 \mathrm{~min}$ each. When embedding the tissue, metal cassette molds were preferred, because, unlike plastic molds, the bottom surface tended to remain extremely flat. The diaphram was placed on this surface of the mold when embedding which allowed for sections of the entire surface area of the very thin diaphram to be obtained. Paraffin sections were cut at 2-3 microns, floated on to a $43^{\circ} \mathrm{C}$ waterbath containing $0.01 \%$ poly-L-lysine and picked up on Fischer Superfrost Plus brand coated slides. Hematoxylin staining was performed using Gill \#2 Hematoxylin for 1 minute followed by 30 second bluing in Tris buffered saline (TBS), pH 7.4, consisting of $6.06 \mathrm{~g}$ Trizma $\mathrm{HCl}, 8.77 \mathrm{~g} \mathrm{NaCl}, 43.7 \mathrm{mls} 1 \mathrm{~N} \mathrm{HCl}$ in $1000 \mathrm{mls}$ distilled water. The Eosin stain consisted of $0.4 \%$ Eosin $Y, 0.02 \%$ phyloxine B, and $0.3 \%$ glacial acetic acid in $70 \%$ ethanol. This was applied for 1 minute then 
rinsed briefly in $95 \%$ ethanol before finishing dehydration through $100 \%$ isopropyl, xylene and coverslipping out of Propar (Anatech Labs, CA.). Nontoxic Propar is prefered as the final stage of dehydration because it eliminates the technicians exposure to xylene while coverslipping.

\section{Detection of Endogenous Peroxidase activity}

Peroxidases are cellular enzymes whose intracellular antimicrobial functions are well known (Klebanoff, 1971; McRipley, R.J and A.J. Sbarra, 1967). They are found predominately in neutrophils, macrophages and eosinophils and function to detoxify cellular peroxides used in phagocytosis (Figure 1). Peroxidases can be utilized as a histochemical tool by taking advantage of their ability to reduced hydrogen peroxide to yeild water and atomic oxygen. Chromagens are molecules that can serve as electron donors in this reaction sustaining the catalysis of hydrogen peroxide while becoming oxidized themselves. Upon oxidation the chromagen forms a highly insoluable colored precipitate that can serve as a marker for enzymatic activity (Boenisch, 1989). One of these chromogens is $3^{\prime}, 3^{\prime}$-Diaminobenzidine (DAB) that, upon oxidation, forms a brown precipitate that is highly insoluable in alcohols and organic solvents.

To determine endogenous peroxidase activity in the infected tissue 3 micron paraffin sections were deparaffinized in xylene and rehydrated through graded alcohols, as previously described, to water. The slides were then rinsed in TBS, tapped gently on a paper towel and placed face up in a slide incubator. A commercially prepared DAB solution (BioTek labs, Los Angeles, CA.) was applied directly to the tissue and incubated for 10 minutes at room temperature. Following incubation with $\mathrm{DAB}$, the slides were rinsed in water, counterstained 


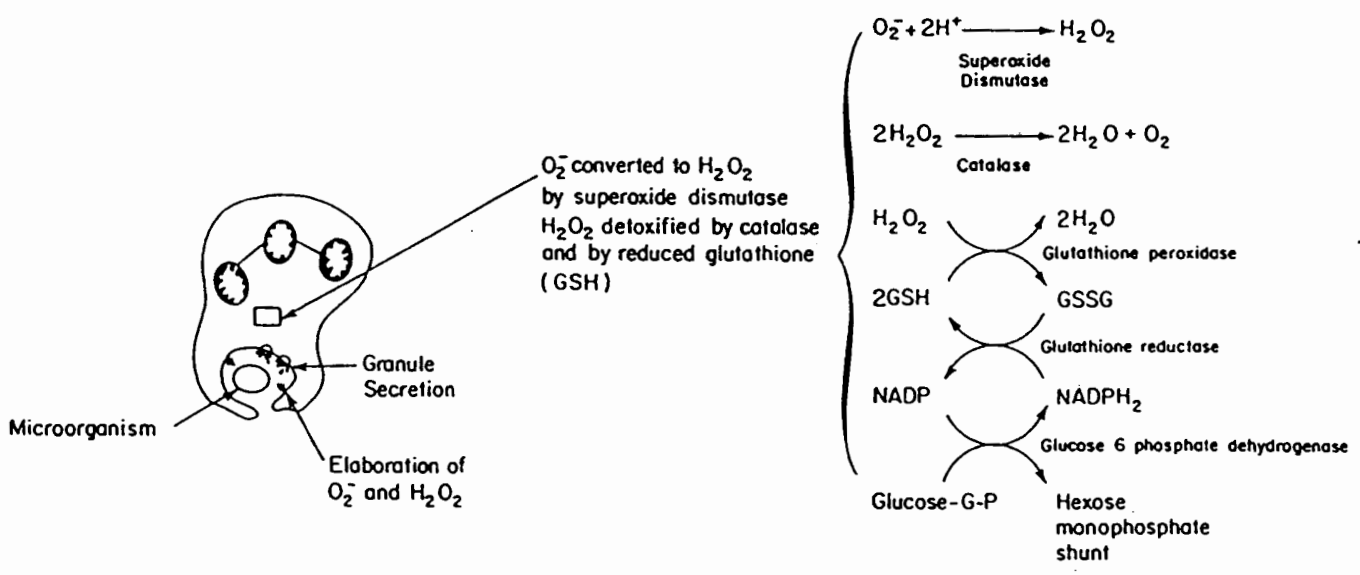

Figure 1 - Diagram showing relationship of peroxide use by granulocytes in host defense (Babior, 1990). 
with Gill's \#2 hematoxylin for one minute, blued in TBS for one minute and dehydrated and coverslipped as previously described.

\section{Immunohistochemical Staining}

Immunohistochemistry relies on the use of antibodies to localize a given antigen which serves as the first step in a series that will eventually label the desired antigen with a colored precipitate. The method used here is referred to as the Avidin-Biotin Complex or $\mathrm{ABC}$ method. The $\mathrm{ABC}$ method requires the attachment of a primary antibody to an antigen, followed by a secondary biotinylated "link" antibody specific for the primary antibody. A preformed avidin-biotin complex is then added (which is made up beforehand to allow formation of the "complex"). The avidin in this complex contains covalently bound enzyme molecules. This complex attaches to the biotin molecule of the secondary link antibody by one of the free binding sites on an avidin molecule in the complex. These free binding sites are ensured by incubating the complex in a relative excess of avidin (Hsu et. al., 1981). Application of the appropriate chromogen at this time results in a precipitate at the site of primary antibody attachment.

The primary antibody used was rabbit anti-human myeloperoxidase (Dako code \# A 398), which labels only the granules in neutrophils granulocytes and, to a lesser extent, the granules of monocytes. Because this antibody is thought to be highly conserved among species, it was predicted to cross react well with granules of murine neutrophil granulocytes. Immunostaining of normal mouse tissue confirmed this assumption. A dilition of 1:20,000, made up in a diluting solution consisting of $0.3 \%$ BSA (Sigma Chemical Co., St. Louis, MO.) in TBS containing $0.1 \%$ sodium azide, was found to give excellent overall staining with minimal 
background on murine tissue. Goat anti rabbit biotinylated secondary (Vector Labs, catalog \# BA 1000) was used at 1:400 in the diluting solution.

Immunostaining was performed on the Tech-Mate 1000 automated stainer (BioTek Solutions, Los Angeles, CA.). This stainer relies on capillary action to draw reagents in between two paired slides. The tissue sections are facing one another, but are seperated by a 150 micron gap that is the result of 75 thick coatings on the top $1 / 3$ of each slide and small pieces of the bottom corners (Fig 2). This gap allows for sufficent exposure of the tissue sections to each reagent while simultaneously requiring minimum quantities. Table 1 describes the entire protocol in detail, including incubation times. All reagents listed in Table 1 are provided in the detection kits that accompany the TechMate 1000 with the exception of the previously described primary and secondary antibodies, the quenching solution and the Tween/DMSO solution. The quenching solution, used to eliminate endogenous peroxidase, consists of $80 \%$ methanol $(80 \mathrm{mls}), 0.37 \%$ hydrogen peroxide (10mls of a $37 \%$ solution) and $0.01 \%$ sodium azide $(10 \mathrm{mls}$ of a $0.1 \%$ stock solution). Two percent Tween 20 with 5\% DMSO is used to permeablize the tissue prior to primary antibody exposure. Following immunostaining, which includes hematoxylin counterstain and bluing, the slides are dehydrated as previously described and coverslipped out of Propar clearant.

\section{Microscopy}

The tissue observed from each experimental host was prepared in such a way that allowed for a high degree of certainty that the actual number of infection sites were represented in the paraffin sections. This was acheived by first observing the freshly removed diaphram under the disecting microscope where the larvae are seen without much difficulty. This allows for an initial estimate of 


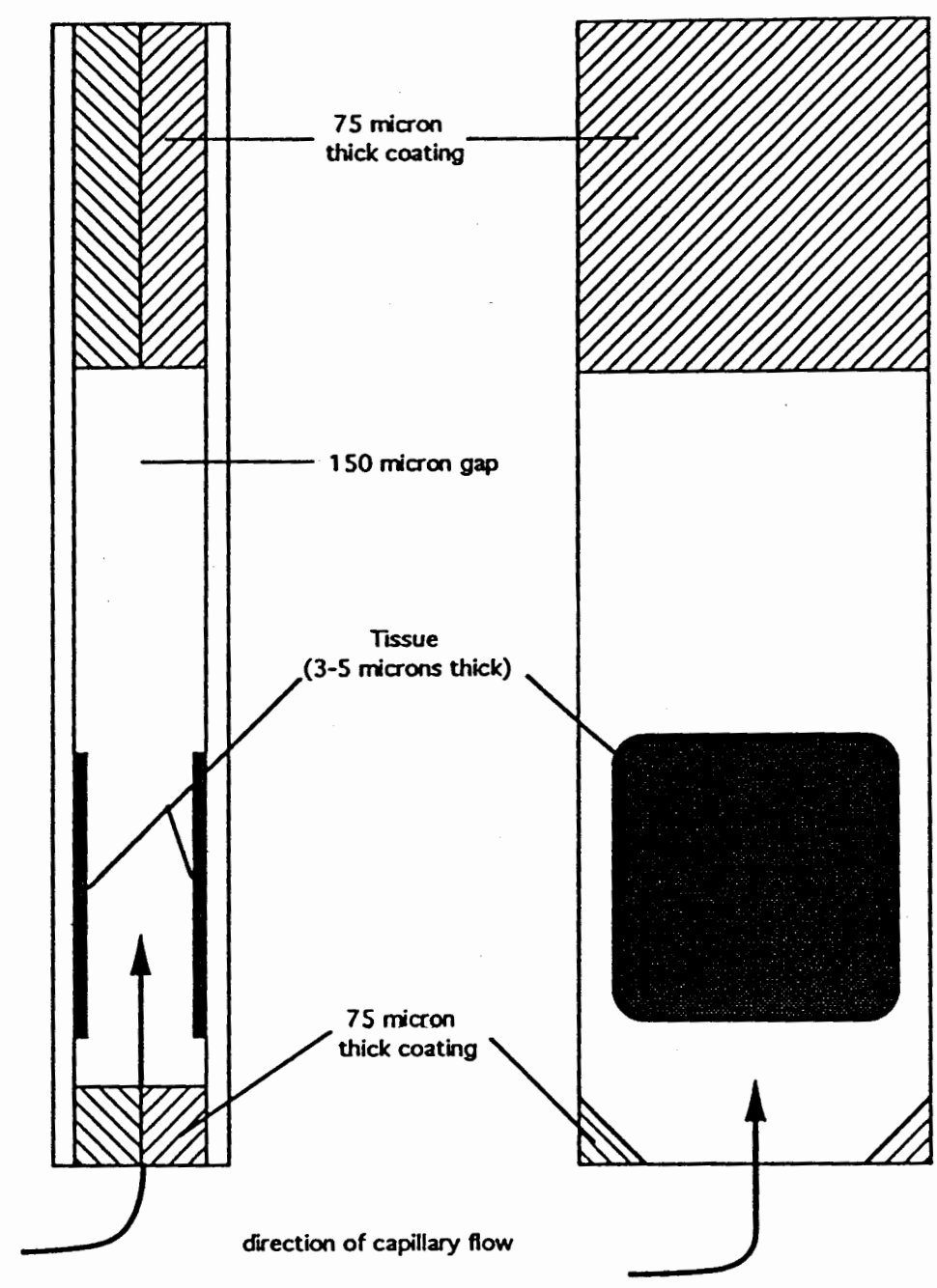

Side view of paired slides

Front view of single slide

Figure 2 - Diagram showing slides used with Tech-Mate 1000 automated stainer and direction of capillary flow. 
Table 1. Chronological listing of immunohistochemical reagents and their minimum and maximum application times. Steps labeled "Pad \#" are for. draining the previous reagent from between the paired slides on one of four absorbant pads. (Protocol courtesy of Oregon Health Sciences University Immunohistochemistry laboratory.)

\begin{tabular}{|c|c|c|c|}
\hline STEP \#: & REAGENT: & MINIMUM TIME: & MAXIMUM TIME: \\
\hline 1. & $\overline{\text { Pad 1 }}$ & $00: 00: 30$ & $00: 00: 30$ \\
\hline 2. & Buffer 1 & $00: 00: 15$ & $00: 05: 00$ \\
\hline 3. & Pad 1 & $00: 00: 30$ & $00: 00: 30$ \\
\hline 4. & $0.2 \%$ Tween DMSO & $10: 10: 00$ & $00: 15: 00$ \\
\hline 5. & Pad 1 & $00: 00: 30$ & $00: 00: 30$ \\
\hline 6. & Buffer 1 & $00: 00: 15$ & $00: 05: 00$ \\
\hline 7. & Pad 1 & $00: 00: 30$ & $00: 00: 30$ \\
\hline 8. & Buffer 1 & $00: 00: 15$ & $00: 05: 00$ \\
\hline 9. & Pad 1 & $00: 00: 45$ & $00: 00: 45$ \\
\hline 10. & Block & $00: 15: 00$ & $00: 20: 00$ \\
\hline 11. & Pad 1 & $00: 00: 30$ & $00: 00: 30$ \\
\hline 12. & Buffer 1 & $00: 00: 15$ & $00: 05: 00$ \\
\hline 13. & Pad 1 & $00: 00: 45$ & $00: 00: 45$ \\
\hline 14. & Primany Antibody & $10: 00: 00$ & $10: 00: 00$ \\
\hline 15. & Pad 1 & $00: 00: 30$ & $00: 00: 30$ \\
\hline 16. & Buffer 1 & $00: 00: 15$ & $00: 05: 00$ \\
\hline 17. & Pad 1 & $00: 00: 30$ & $00: 00: 30$ \\
\hline 18. & Buffer 1 & $00: 00: 15$ & $00: 05: 00$ \\
\hline 19. & Pad 1 & $00: 00: 30$ & $00: 00: 30$ \\
\hline 20. & Buffer 1 & $00: 00: 15$ & $00: 05: 00$ \\
\hline 21. & Pad 1 & $00: 00: 30$ & $00: 00: 30$ \\
\hline 22. & Buffer 1 & $00: 00: 15$ & $00: 05: 00$ \\
\hline 23. & Pad 1 & $00: 00: 30$ & $00: 00: 30$ \\
\hline 24. & Buffer 1 & $00: 00: 15$ & $00: 05: 00$ \\
\hline 25. & Pad 1 & $00: 00: 45$ & $00: 00: 45$ \\
\hline 26. & Secondary Antibody & $00: 45: 00$ & $00: 45: 00$ \\
\hline 27. & Pad 1 & $00: 00: 30$ & $00: 00: 30$ \\
\hline 28. & Buffer 2 & $00: 00: 15$ & $00: 05: 00$ \\
\hline 29. & Pad 1 & $00: 00: 30$ & $00: 00: 30$ \\
\hline 30. & Butfer 2 & $00: 00: 15$ & $00: 05: 00$ \\
\hline 31. & Pad 1 & $00: 00: 30$ & $00: 00: 30$ \\
\hline 32. & Buffer 2 & $00: 00: 15$ & $00: 05: 00$ \\
\hline 33. & Pad 1 & $00: 00: 30$ & $00: 00: 30$ \\
\hline 34. & Buffer 2 & $00: 00: 15$ & $00: 05: 00$ \\
\hline 35. & Pad 1 & $00: 00: 30$ & $00: 00: 30$ \\
\hline 36. & Hydrogen Peroxide & $00: 15: 00$ & $00: 20: 00$ \\
\hline 37. & Pad 2 & $00: 00: 30$ & $00: 00: 30$ \\
\hline 38. & Buffer 2 & $00: 00: 15$ & $00: 05: 00$ \\
\hline 39. & Pad 2 & $00: 00: 30$ & $00: 00: 30$ \\
\hline 40. & Butfer 2 & $00: 00: 15$ & $00: 05: 00$ \\
\hline 41. & Pad 2 & $00: 00: 30$ & $00: 00: 30$ \\
\hline 42. & Buffer 2 & $00: 00: 15$ & $00: 05: 00$ \\
\hline 43. & Pad 2 & $00: 00: 30$ & $00: 00: 30$ \\
\hline 44. & Buffer 2 & $00: 00: 15$ & $00: 05: 00$ \\
\hline 45. & Pad 2 & $00: 00: 30$ & $00: 00: 30$ \\
\hline 46. & Butfer 2 & $00: 00: 15$ & $00: 05: 00$ \\
\hline
\end{tabular}


Table 1. (Continued)

\begin{tabular}{|c|c|c|c|}
\hline 47. & Pad 2 & $00: 00: 45$ & $00: 00: 45$ \\
\hline 48. & $A B C$ & $00: 45: 00$ & $00: 45: 00$ \\
\hline 49. & Pad 2 & $00: 00: 30$ & $00: 00: 30$ \\
\hline 50. & Buffer 2 & $00: 00: 15$ & $00: 05: 00$ \\
\hline 51. & Pad 2 & $00: 00: 30$ & $00: 00: 30$ \\
\hline 52. & Buffer 3 & $00: 00: 15$ & $00: 05: 00$ \\
\hline 53. & Pad 2 & $00: 00: 30$ & $00: 00: 30$ \\
\hline 54. & Buffer 3 & $00: 00: 15$ & $00: 05: 00$ \\
\hline 55. & Pad 2 & $00: 00: 30$ & $00: 00: 30$ \\
\hline 56. & Buffer 3 & $00: 00: 15$ & $00: 05: 00$ \\
\hline 57. & Pad 2 & $00: 00: 30$ & $00: 00: 30$ \\
\hline 58. & Buffer 3 & $00: 00: 15$ & $00: 08: 00$ \\
\hline 59. & Pad 2 & $00: 00: 45$ & $00: 00: 45$ \\
\hline 60. & DAB & $00: 10.00$ & $00: 10: 00$ \\
\hline 61. & Pad 3 & $00: 00: 30$ & $00: 00: 30$ \\
\hline 62. & Buffer 3 & $00: 00: 30$ & $00: 08: 00$ \\
\hline 63. & Pad 3 & $00: 00: 30$ & $00: 00: 30$ \\
\hline 64. & $\mathrm{DAB}$ & $00: 10: 00$ & $00: 10: 00$ \\
\hline 65. & Pad 3 & $00: 00: 30$ & $00: 00: 30$ \\
\hline 66. & Buffer 3 & $00: 00: 30$ & $00: 08: 00$ \\
\hline 67. & $\mathrm{Pad} 3$ & $00: 00: 30$ & $00: 00: 30$ \\
\hline 68. & $\mathrm{DAB}$ & $00: 10: 00$ & $00: 10: 00$ \\
\hline 69. & Pad 3 & $00: 00: 30$ & $00: 00: 30$ \\
\hline 70. & Water & $00: 00: 30$ & $00: 08: 00$ \\
\hline 71. & Pad 3 & $00: 00: 30$ & $00: 00: 30$ \\
\hline 72. & Water & $00: 00: 30$ & $00: 08: 00$ \\
\hline 73. & Pad 3 & $00: 00: 30$ & $00: 00: 30$ \\
\hline 74. & Hematoxylin & $00: 01: 00$ & $00: 01: 00$ \\
\hline 75. & Pad 3 & $00: 00: 30$ & $00: 00: 30$ \\
\hline 76. & Hematoxylin & $00: 01: 00$ & $00: 01: 00$ \\
\hline 77. & Pad 3 & $00: 00: 30$ & $00: 00: 30$ \\
\hline 78. & Hematoxylin & $00: 01: 00$ & $00: 01: 00$ \\
\hline 79. & $\operatorname{Pad} 3$ & $00: 00: 30$ & $00: 00: 30$ \\
\hline 80. & Water & $00: 00: 30$ & $00: 08: 00$ \\
\hline 81 & Pad 3 & $00: 00: 30$ & $00: 00: 30$ \\
\hline 82. & Water & $00: 00: 30$ & $00: 08: 00$ \\
\hline
\end{tabular}


infectious larvae. This is later confirmed by histological examination which requires the method of fixation and embedding previously described to assure sections representative of the surface area of the tissue. Because the diaphram is very thin (approximately 200 microns), uneven embedding of the tissue will result in sectioning through one area completely before facing into another. In this experiment sections were obtained that represented greater than $90 \%$ of the tissue surface and most of the larvae and infection sites present. It is important to mention that we were not attempting to measure reproductivity capacity and the results should not be interpreted in this manner. Rather, we were attempting to obtain individual infection sites for comparison. 


\section{RESULTS}

\section{Histological evaluation of Hematoxylin and Eosin stains}

Hematoxylin and eosin stains were examined for the purpose of comparing histological features only. Of interest were areas of inflammation with or without visible larvae, visible larvae and muscle fibers that fit description of early stages of infection including replacement of muscle-specific components with whorls of smooth membranes and aggregates of partially dysfunctional mitochondria and enlargement of nuclei which develop very prominent nucleoli (Despommier, 1990) (Fig. 3). In general the inflammation seen appeared to consist mainly of granulocytes and macrophages, but no attempt to quantitate was made at this time.

5 dpi.- Each of the three infected diaphrams appeared normal at this time point (Fig. 4). There was no evidence of myositis or individual muscle fiber damage that would result from early stages of the muscle phase of infection. It was assumed that at this point the larvae had not yet reached this section diaphram.

$7 \mathrm{dpi}$ - As in the 5 days post infected tissue this stage of infection the diaphram muscle was intact and with a normal appearance. Again it was assumed that the larvae had not yet reached this section diaphram.

$11 \mathrm{dpi}$ - Seven larvae were visible in the T. spiralis infected tissue and also in the T. pseudospiralis infected tissue. In each case the larvae had not begun to coil up, suggesting an early stage of infection (Fig. 5 and 6). There were no signs of inflammation in general or around the infected muscle fibers. There were also indvidual muscle fibers that fit desciptions of early stages of the muscle phase of infection. Tissue from the T.sp. 3 infected mouse had no visible larvae and only two fibers suggestive of early stage muscle infection. 


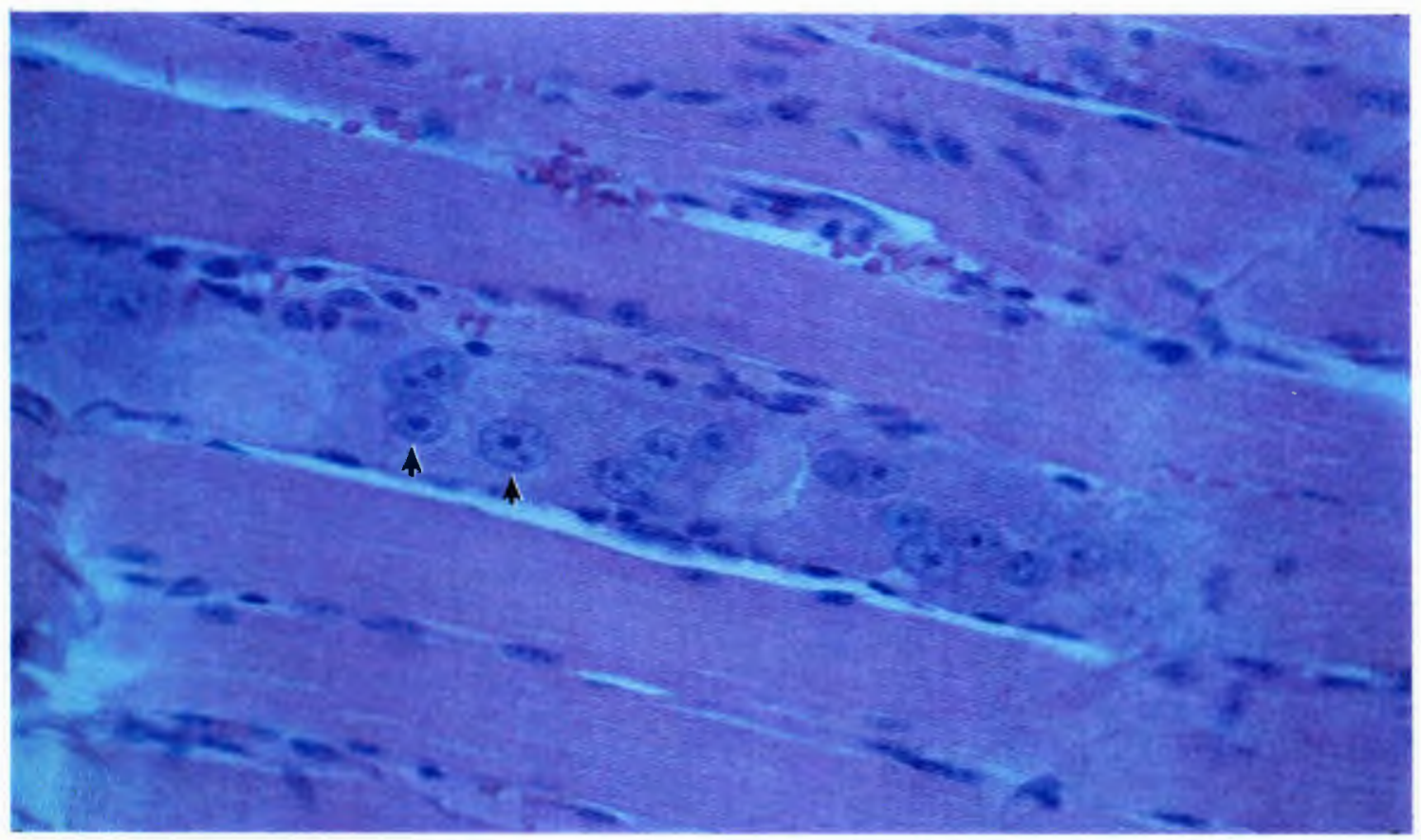

Figure 3 - T. spiralis infected diaphram showing muscle cell characteristic of early stage of infection. Arrows point to characteristic enlarged nuclei. Hematoxylin and eosin counterstain. (170X).

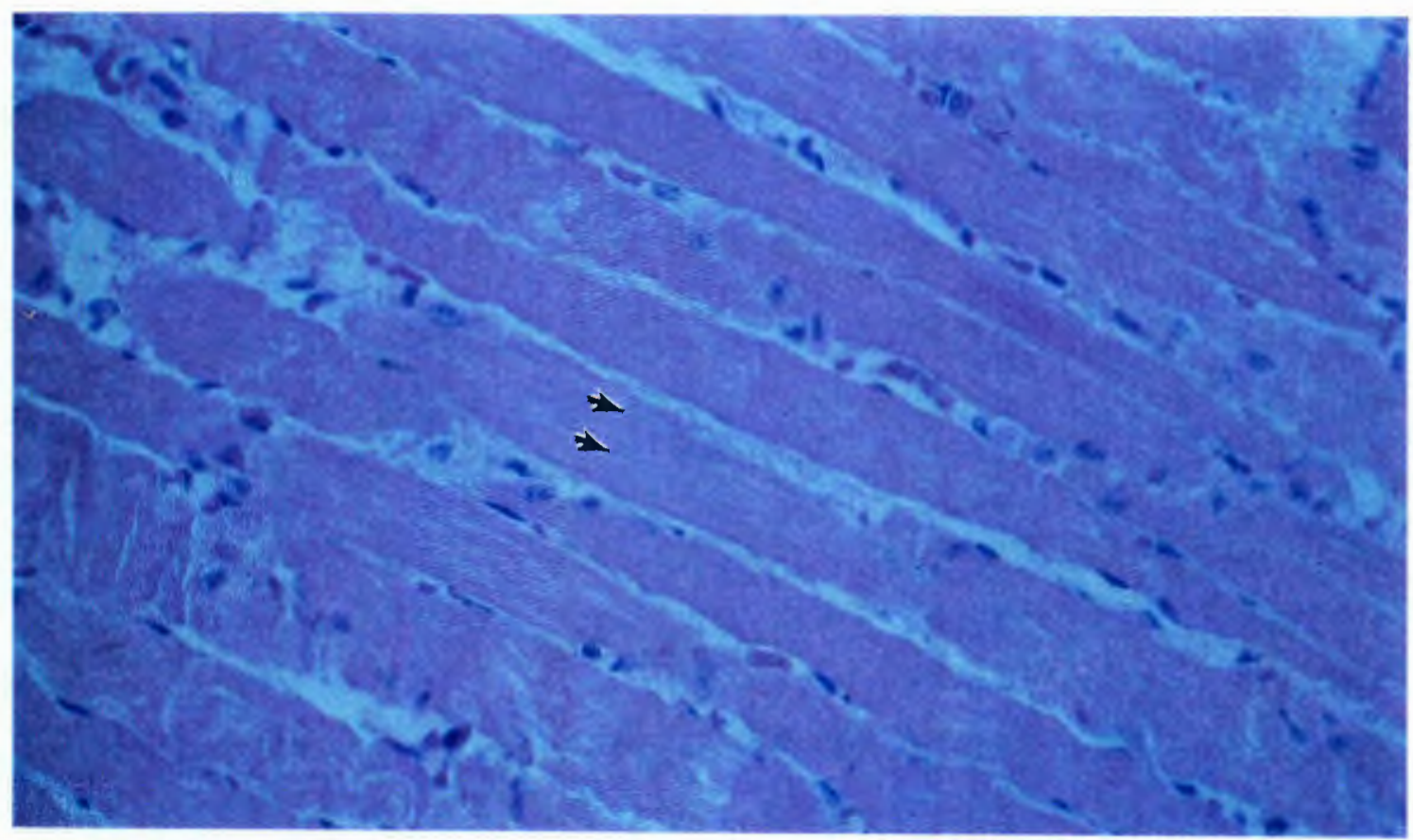

Figure 4 - Normal murine diaphram tissue stained with hematoxylin and eosin. Arrows indicate striations. (170X). 


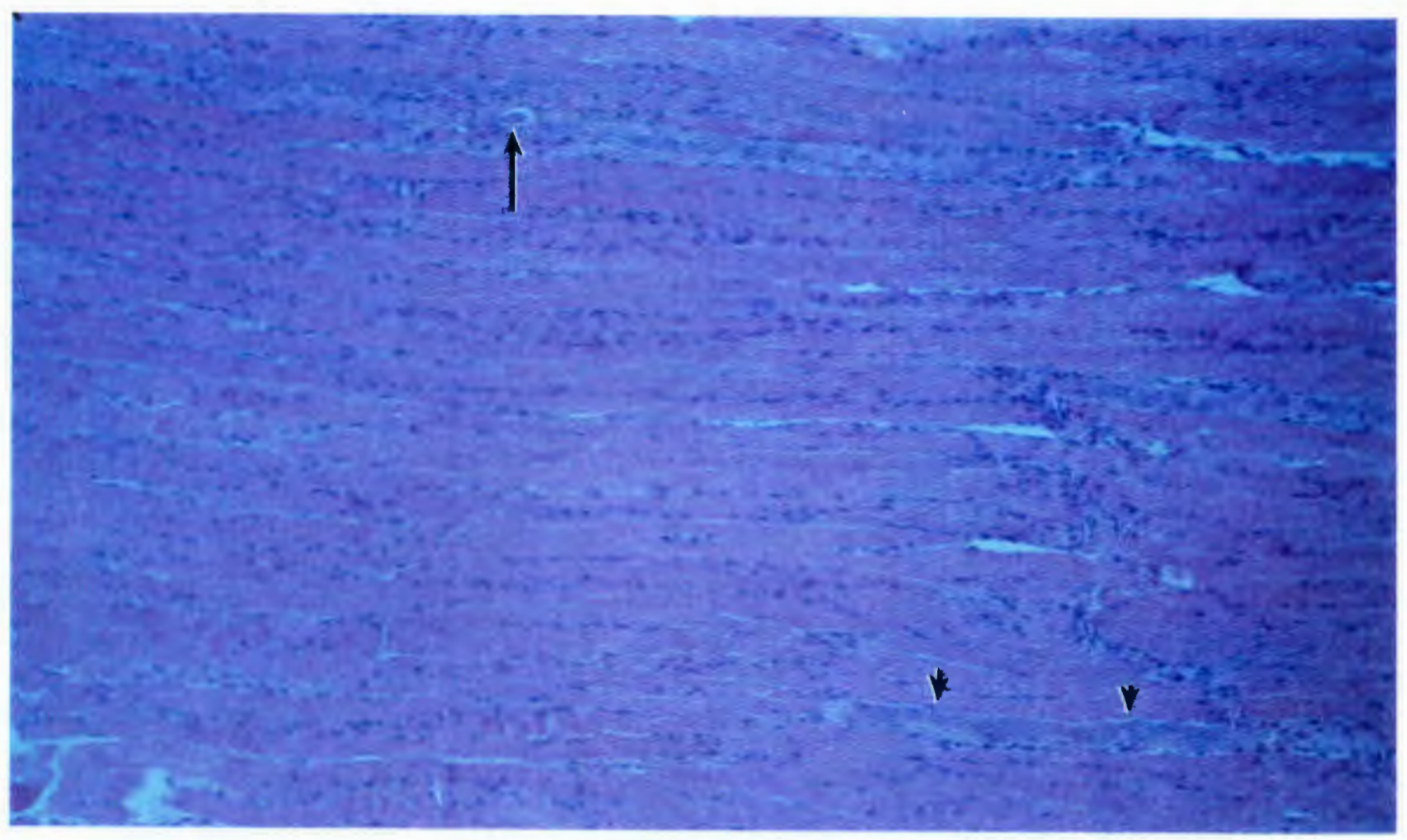

Figure 5 - T. spiralis infected diaphram 11 dpi. Large arrow points to larvae. Small arrows show damaged cells without visible larvae. Hematoxylin and eosin counterstain. (43X).

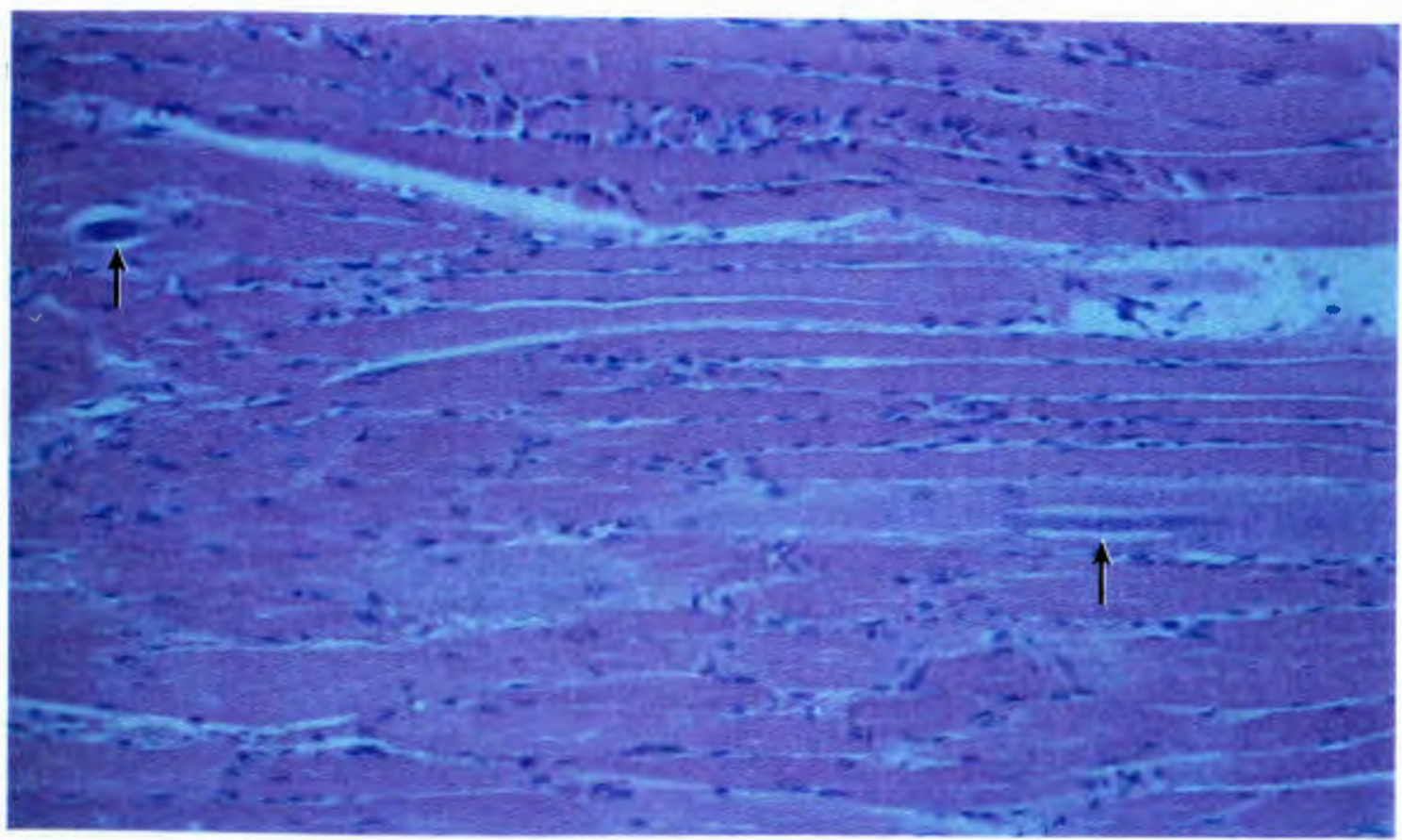

Figure 6 - T. pseudospiralis infected murine diaphram 11 dpi showing two larvae (arrows) without any surrounding inflammation. Hematoxylin and eosin counterstain. (43X). 
$18 \mathrm{dpi}$ - The T. spiralis infected diaphram contained over 50 visible larvae, most of which were coiled and encysted. Inflammation around these areas appeared heavy with the cellular infiltrate occupying areas on both sides of the visible larvae. The inflammation also extended throughout the length of the fiber, tapering off at each end. There were also many fibers which exibited the characteristics of a damaged muscle cell. The tissue infected with $T$. pseudospiralis had 34 visible larvae, none of which had any sign of cyst formation. There was also no inflammation surrounding the larvae or infected fibers. Three larvae were present in the T. sp. 3 infected tissue, one of which exhibited nurse cell formation. Minimal inflammation was present around the infected fibers or larvae and only two other muscle fibers exhibited signs of damage.

$20 \mathrm{dpi}$ - At this time point, the T. spiralis tissue again had greater than 50 visible larvae, all in nurse cells. Inflammation around these sites was heavy, similar to the 18 dpi tissue (Fig 7). The tissue from the T. pseudospiralis infected mouse had 24 visible larvae, 18 of which showed coiling. As expected with this species none of these were encysted. Inflammation around the infected fibers was absent in all exept two, which had minimal inflammation (Fig. 8). No general myositis was observed. Six larvae were visible in the diaphram from the T. sp. 3 infected mouse, two of which could be seen coiled up within the muscle cell. The adjacent area exhibited minor inflammation as compared to the $T$. spiralis tissue of the same time period (Fig. 9).

\section{Endogenous Peroxidase Activity}

Application of DAB alone confirmed previous reports on the lack on peroxidase activity by the Trichinella larvae or, in the case of T. sp. 3 and T. 


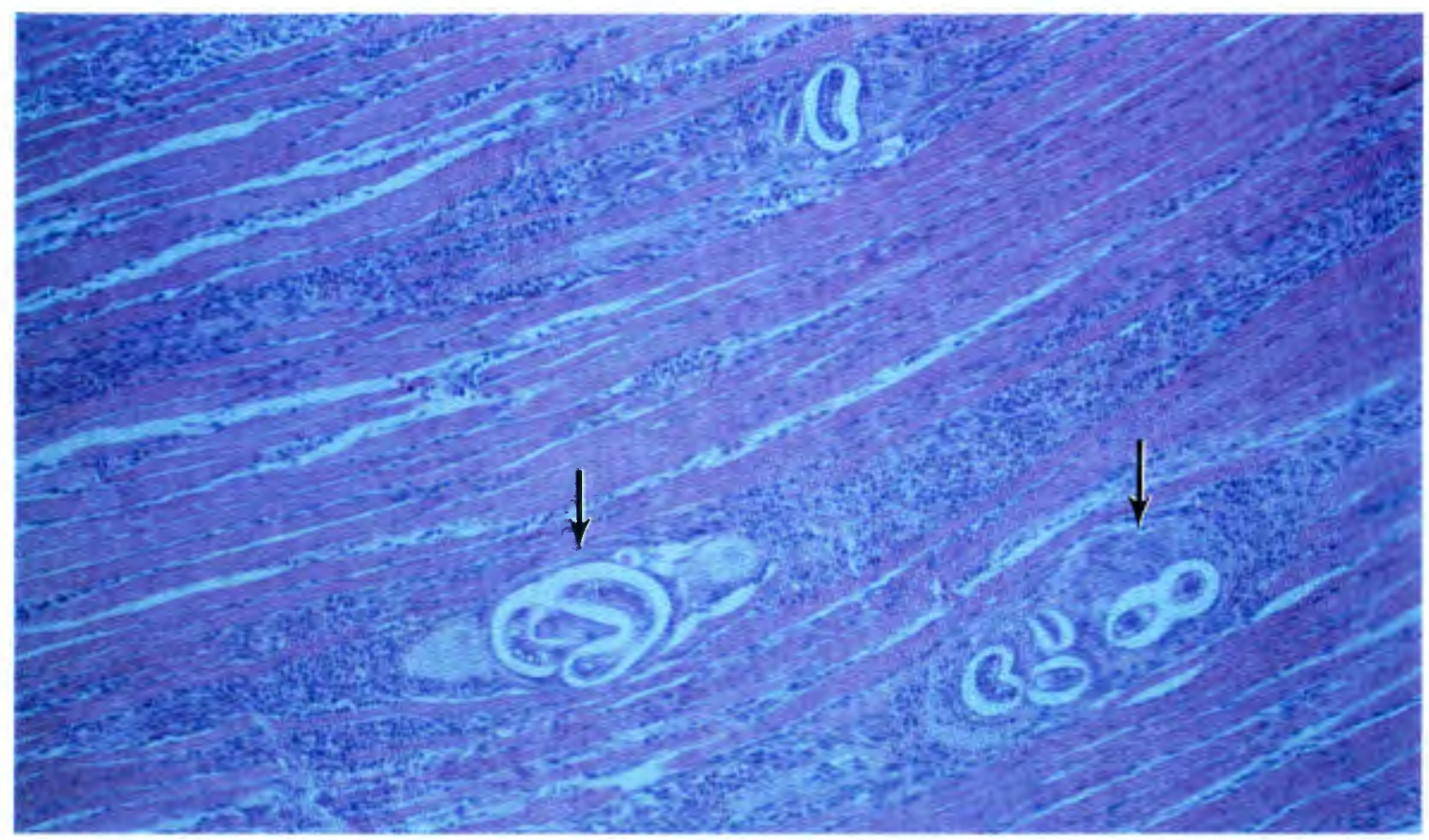

Figure 7 - T. spiralis infected tissue 20 dpi. Arrows indicate encysted larvae surrounded by large inflammatory response. Hematoxylin and cosin stain. (43X).

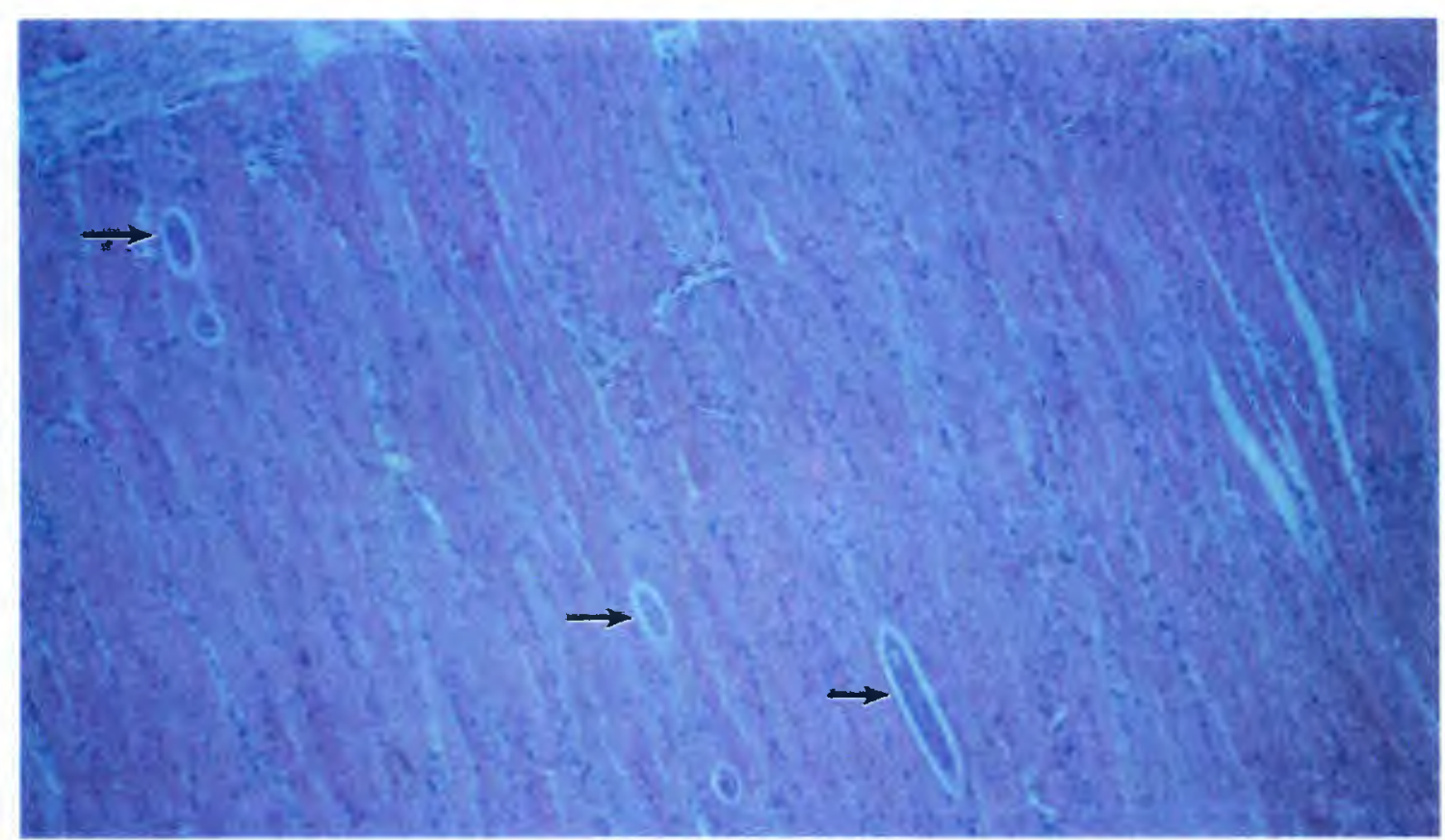

Figure 8 - T. psuedospiralis infected murine diaphram $20 \mathrm{dpi}$. Arrows indicate several larvae. Note absense of any surrounding inflammatory response. Hematoxylin and eosin counterstain. (43X). 


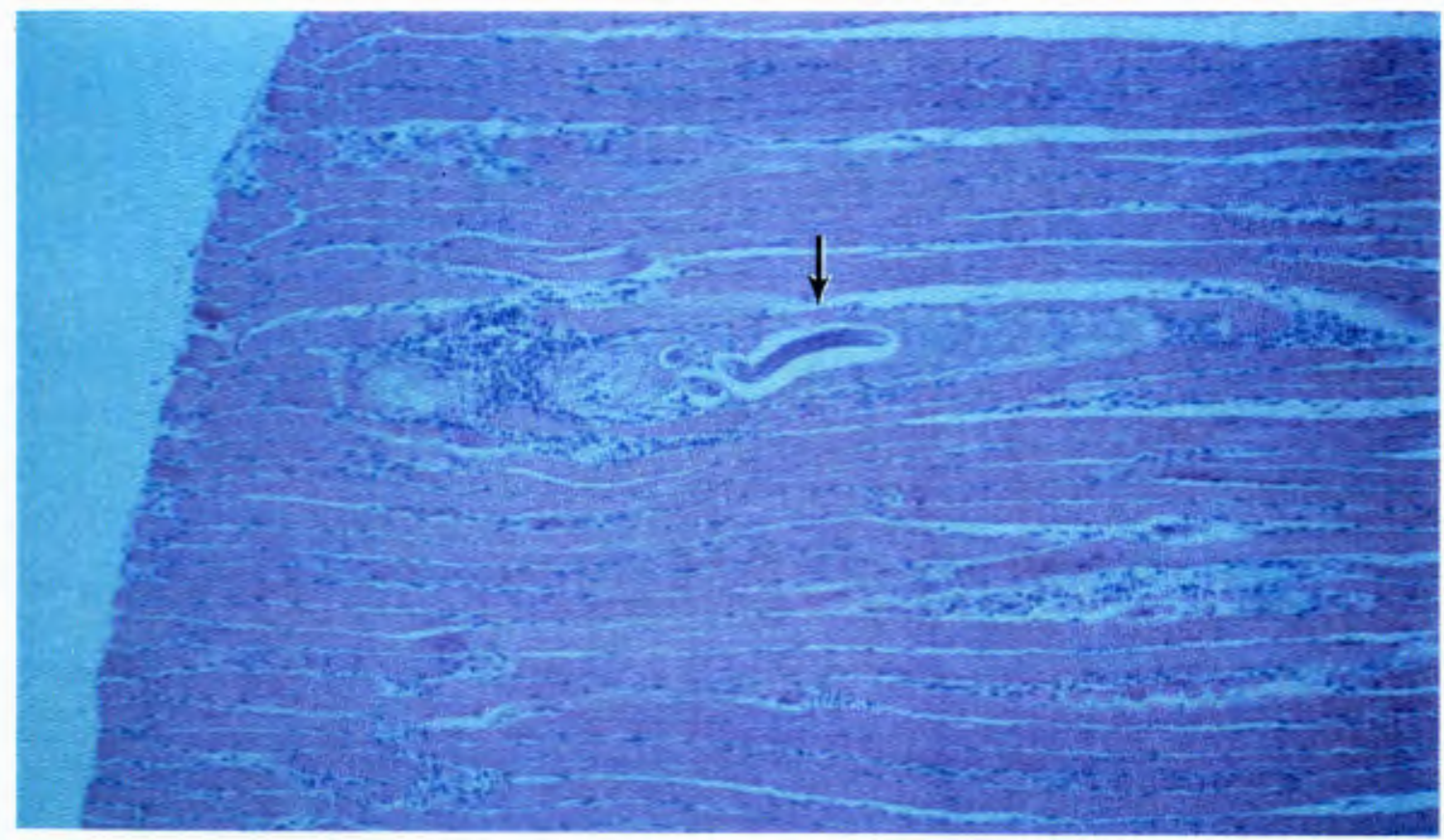

Figure 9 - Murine diaphram 20 dpi with T.sp. 3. Arrow indicates encysted larvae surrounded by small inflammatory response. Hematoxylin and eosin counterstain. (43X). 
spiralis, its surrounding nurse cell (Stewart, 1982). It also confirmed that normal muscle cells also did not exibit endogeous peroxidase activity.

Immunohistochemical Staining for Myeloperoxidase

The results of immunohistochemical staining for myeloperoxidase are presented in Table 2. Staining was quanitified with regards to areas of the tissue where larvae were observed when possible. In each case that positive staining was seen, the colored reaction products remained within cells that resembeled neutrophils. The 20 dpi tissue from the T. spiralis infected mouse contained a large number of positive staining cells adjacent to the larvae and nurse cells (Fig. 10,11,12). T. pseudospiralis infected tissue from the same time periods was absent of positive staining inflammatory cells around the infected muscle fibers (Fig. 13). The T. sp. 3 tissue seemed to fall somewhere inbetween these two with positive staining cells surrounding the infected fiber, but not in the numbers seen in the T. spiralis tissue (Fig. 14). 
Table 2 - Table showing immunohistochemical staining results. (NI) refers to larvae infected muscle cells without any visible inflammation. Staining grades are as follows : (1) - less than 10 positive cells in a 40X objective feild of view; (2) - greater than 10 but less than 50 positive staining cells in a $40 \mathrm{X}$ field of view; (3) greater than 50 positive cells in a 40X field of view.

\begin{tabular}{|c|c|c|c|c|c|c|}
\hline \multirow[b]{2}{*}{ T. peudosplralis } & \multirow{2}{*}{$\mid \begin{array}{c}\text { total } \\
\begin{array}{c}\text { of larvae } \\
\text { observed }\end{array}\end{array}$} & \multirow{2}{*}{$\begin{array}{c}\text { \# of total } \\
\text { observed larvae } \\
\text { w/nurse cells }\end{array}$} & \multicolumn{4}{|c|}{ Immunohistochemical Grading } \\
\hline & & & $\mathbf{N I}$ & 1 & 2 & 3 \\
\hline 5 dpi & 0 & 0 & & & & \\
\hline $7 \mathrm{dpi}$ & 0 & 0 & & & & \\
\hline $11 \mathrm{dpi}$ & 7 & 0 & 7 & & & \\
\hline $18 \mathrm{dpi}$ & 34 & 0 & 34 & & & \\
\hline 20 dpi & 24 & 0 & 22 & 2 & & \\
\hline T. sp. 3 & & & & & & \\
\hline $5 \mathrm{dpi}$ & 0 & 0 & 0 & & & \\
\hline $7 \mathrm{dpi}$ & 0 & 0 & 0 & & & \\
\hline $11 \mathrm{dpi}$ & 0 & 0 & 0 & & & \\
\hline $18 \mathrm{dpi}$ & 2 & 1 & 1 & 1 & & \\
\hline 20 dpi & 4 & 2 & 3 & 1 & & \\
\hline T. spiralls & & & & & & \\
\hline $5 \mathrm{dpi}$ & 0 & 0 & & & & \\
\hline 7 dpi & 0 & 0 & & & & \\
\hline $11 \mathrm{dpi}$ & 7 & 1 & & 7 & & \\
\hline $18 \mathrm{dpi}$ & $>50$ & all & & & $10 \%$ & $90 \%$ \\
\hline $20 \mathrm{dpi}$ & $>50$ & all & & & & all \\
\hline
\end{tabular}




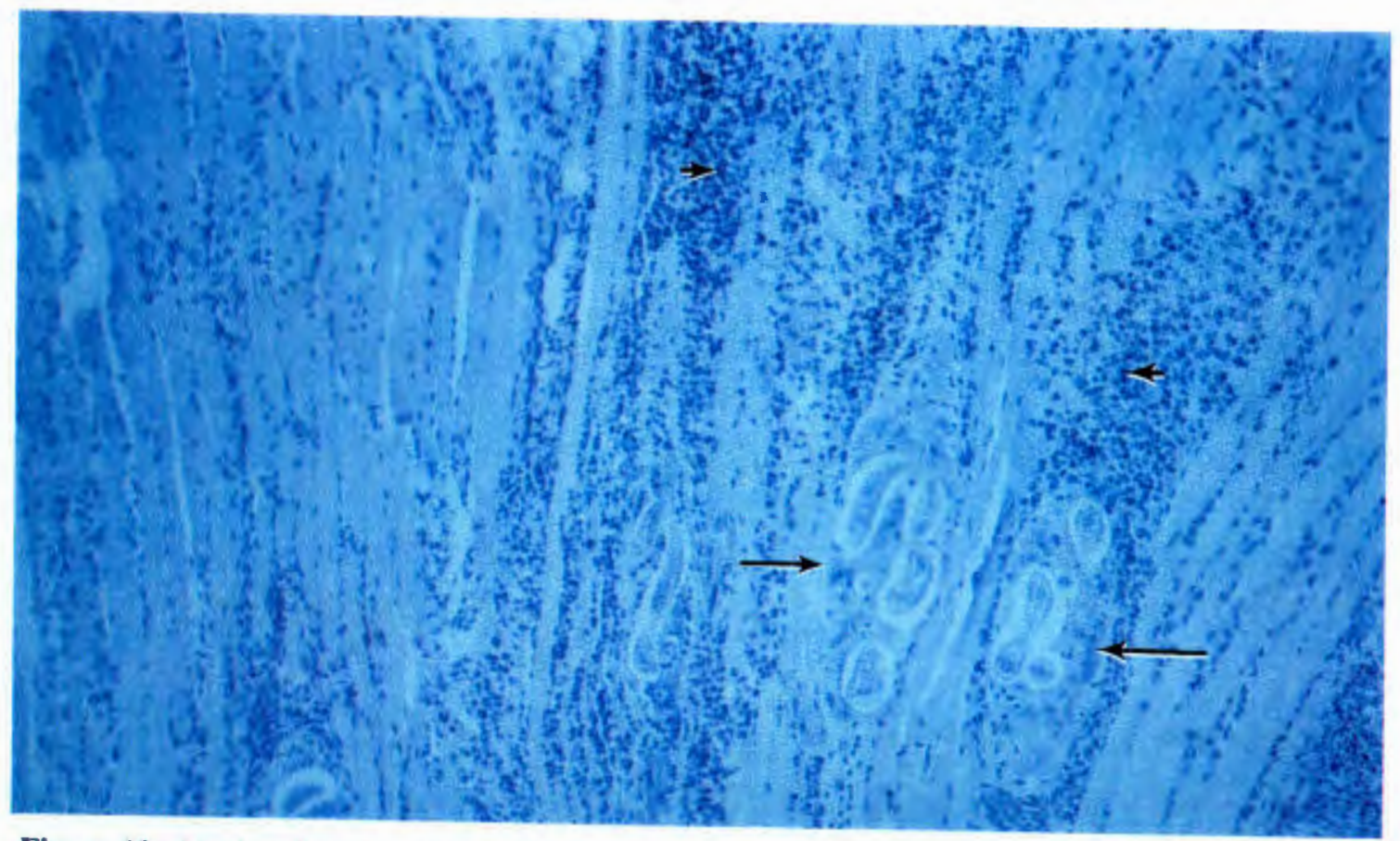

Figure 10 - Murine diaphram 20 dpi with $T$. spiralis stained with anti-myeloperoxidase 1:20,000. Large arrows indicate encysted larvae. Small arrows point out areas containing large numbers of positively
staining cells. (43X). 


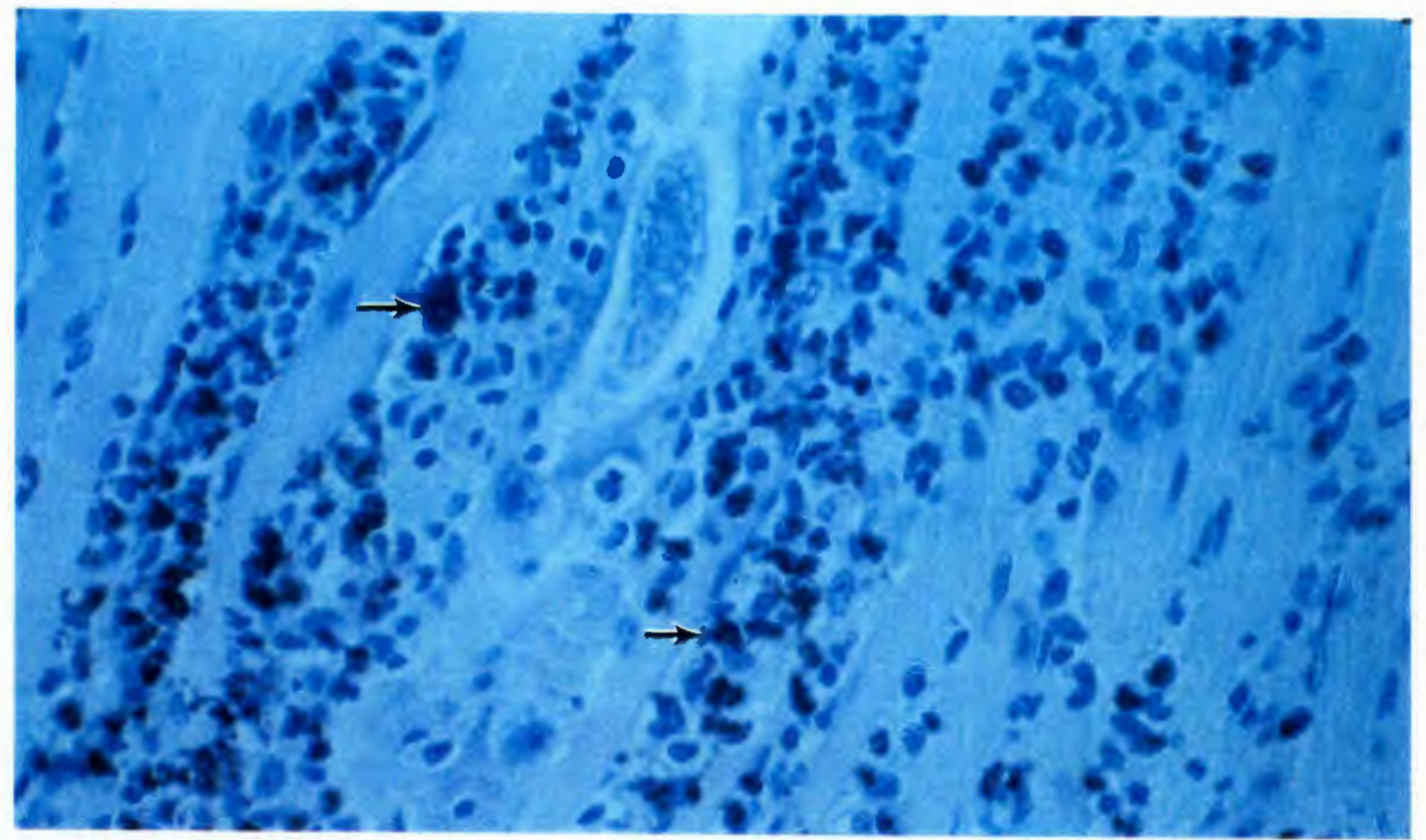

Figure 11 - Murine diaphram 20dpi with $T$, spiralis and stained with anti-myeloperoxidase. Arrows show positive staining cells. (170X).

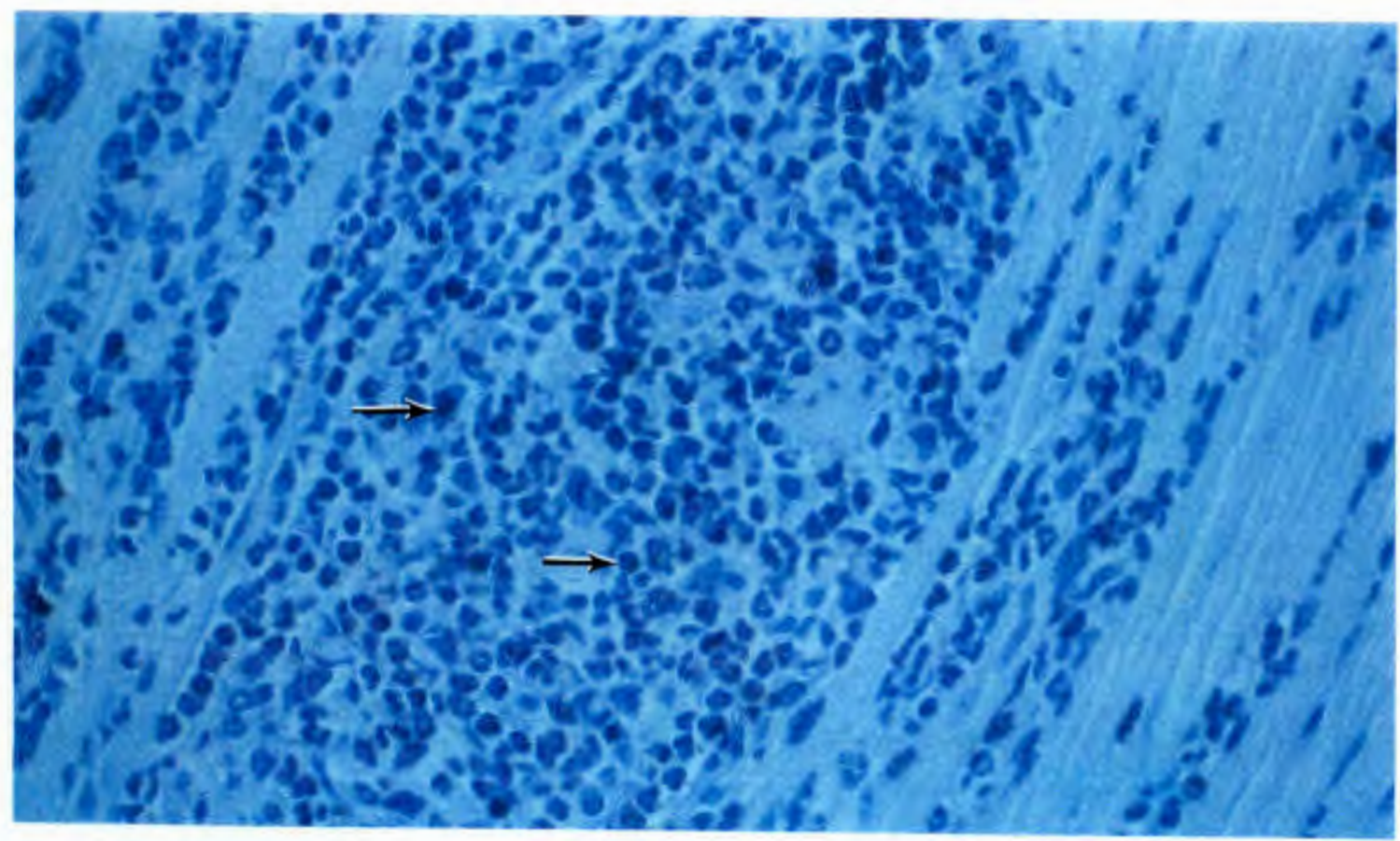

Figure 12 - Large site of inflammation in murine diaphram 20 dpi with $T$. spiralis stained with antimyeloperoxidase. Arrows show positive staining cells. (170X). 


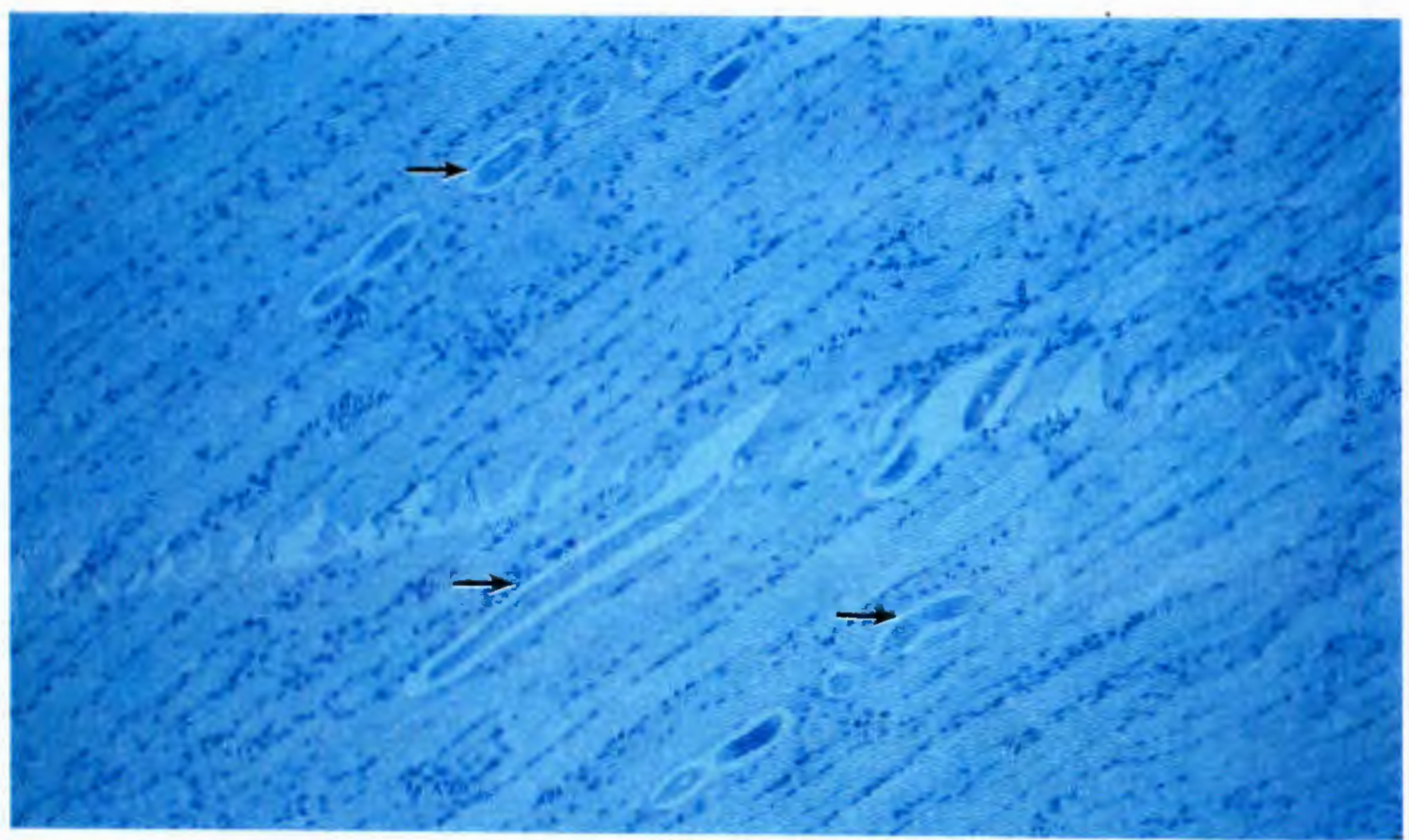

Figure $13-T$. pseudospiralis infected diapram 20 dpi stained with anti-myeloperoxidase 1:20,000. Arrows show numerous larvae without any surrounding inflammation or positive staining cells. (43X).

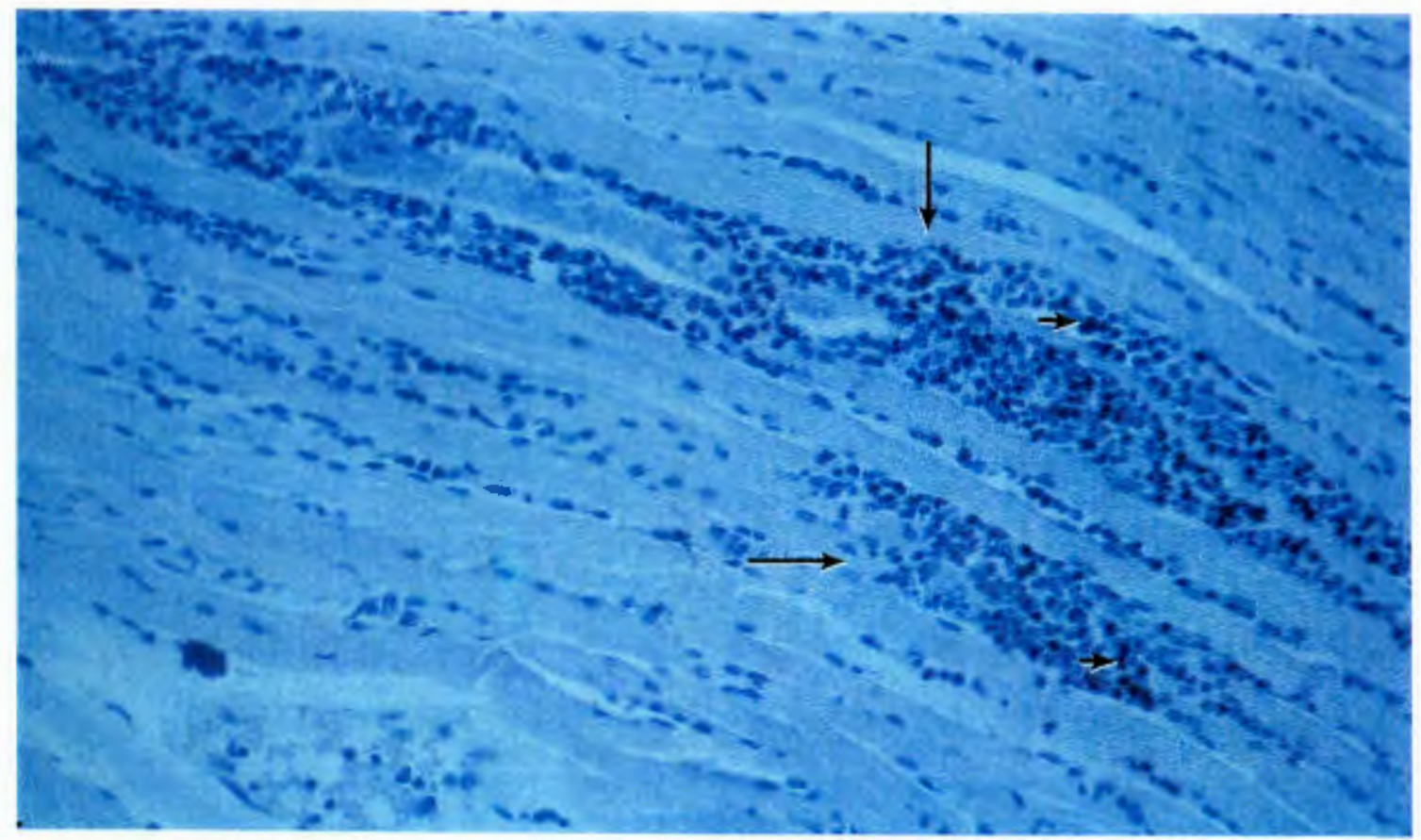

Figure 14 - Murine diaphram 18 dpi with $T$. sp. 3 stained with anti-myeloperoxidase 1:20.000. Large arrow shows site of infection with surrounding positive cells (small arrows). (43X). 


\section{DISCUSSION}

It was the purpose of this experiment to examine the inflammatory response, especially that of the neutrophil, generated by three species of Trichinella; T. spiralis, T. pseudospiralis, and T. sp. 3 in the MRL++ mouse during a 20 day period post oral infection. Of particular interest was the timing of neutrophil arrival and the degree to which this cell type participated in the myositis of infected animals. Previous studies have shown that the muscle phase of infection in the rat by $T$. spiralis and $T$. pseudospiralis are accompanied by myositis, the response being much greater in T. spiralis (Smith and Castro, 1978). Others have shown that peroxidase activity in diaphrams of infected mice increases up to 20 days post infection, implying an increase in neutrophils during this time period (Stewart et. al., 1982). Our study is in agreement with these in that we show both an increase in myositis in the infected tissue and an increase in neutrophils. The small sample size used may present a concern to some but is justified for several reasons. First, we were able to obtain a extremely uniform sample group of mice that were parented from littermates within 4 days of each other. Also, we obtained all males which eliminated questions over any observed differences being sex related. Most importantly we were comparing individual infection sites and not individual mice. We justify this based on numerous previous experiments with all three species of Trichinella that have been consistent with the data presented here.

The use of immunohistochemistry to detect the presense of myeloperoxidase is advantageous because it allows for both histological examination of the sites of inflammation and a quick method of determining a 
relatively accurate estimate of the number of neutrophils at these sites. We think this is important because resulted in several interesting observations.

First, for all three species of Trichinella the changes in the muscle fibers that accompany the early stages of larval infection were observed to be independant of neutrophil migration. In every case these changes could be observed several days before myeloperoxidase positive cells or cells containing endogenous peroxidase were observed in the tissue. This early phase of the muscle stage of infection is a dynamic process. Upon entering the muscle fiber, the larvae encounters a rigid framework of actin and myosin filaments that it must rearrange as it prepares it new residence for an idefinate stay (Despommier, 1990). This is characterized by the damaged cell appearence described earlier. It has been suggested that this process occurs, at least in part, as the result of secretions whose antigens have been immunohistochemically localized within the nucleus (Despommier, 1990). The possibility that the worm is secreting a type of DNA regulatory factor is a fascinating one and is supported by the observation that no inflammatory cells are adjacent to the muscle fiber at the time this occurs.

Interestingly, another important observation made using this technique was that nurse cell formation in $T$. spiralis is timed very closely with the onset of neutrophil inflammation. During our experiment the first larvae seen in this infection were on day 11 and no inflammatory response was present. By day 18 the inflammation surrounding the muscle cell had become severe and it was clear that nurse cells were forming at many of the infection sites. On day 20 nurse cells were clearly formed and the inflammation was still heavy. This observed relationship may be purely coincidental or it may be that nurse cell formation is somehow related to the presense of a large inflammatory response. Whether cyst formation is a protective mechanism of the host cell in response to the larval 
invasion or the inflammatory response surrounding it or somehow directed by the larvae itself is not known. This coincidence is even more intruiging when one considers the observations regarding T. pseudospiralis and T. sp. 3.

T. pseudospiralis infected muscle fibers at any time period were without any nurse cells, as previously reported (Pozio et. al. 1992), and the inflammation around these areas was either absent (days $5,7,11,18$ ) or very minimal (day 20). T. sp. 3 was also without cysts on days $5,7,11,18$ and inflammation was also minimal. However, on day 20 as nurse cell formation began to appear so did a small number of peroxidase positive cells.

Unfortunately, our time periods of tissue collection were not ideal for exploring this possibility further. Future experiments that examined this process between $10 \mathrm{dpi}$ and $20 \mathrm{dpi}$ with tissue collection every 12 to $24 \mathrm{hrs}$ may shed more light on this interesting relationship. Also, these experiments should include an extended time period of tissue collection for T. sp. 3 to allow more time for nurse cell formation and subsequent inflammation. Taken together, these observations suggest the possibility that the presense of neutrophil inflammation having an effect on cyst formation is more than a coincidence.

It is also important to consider the possibility that the neutrophil involvement in Trichinella infections may be due to inhibition of a cell other than the neutrophil, which in turn inhibits its migration to the infected areas. Currently several neutrophil chemoattractants are known. These include Leukotriene B (Hutchinson et. al., 1980), products of the complement cascade (Fernandez et. al., 1978), formylmethionyl peptides of bacterial origin ( Schiffman et. al., 1975), IL-8/Neutrophil-activating peptide, a product of monocytes (Baggiolini et. al., 1989), as well as others. If a Trichinella larvae were able to inhibit secretion of a 
chemokine such as IL-8 or to inactivate it once secreted the neutrophil response would certainly be reduced.

Another possibilitly lies in the downplaying of the expected effects of these molecules by Trichinella. An example of this effect has recently been presented Naccache et. al., 1994. This study examined the role of tyrosine phosphorylase in the upregulation of $\beta 2$-integrins on the surface of neutrophils. Integrins are a key element in the adhesion between neutrophils and endothelial cells (Hynes, 1992). Using the tyrosine kinase inhibitors erbastain and herbimycin surface expression of $\mathrm{CD} 1 \mathrm{lb}$ and $\mathrm{CD} 18$ was shown to be inhibited. It would be very interesting to compare the expression of integrins such as these on neutrophils from mice infected with the three Trichinella species studied in this paper.

In summary, we report that the inflammation associated with $T$. spiralis and $T . s p .3$ infection is accompanied by an increasing number of myeloperoxidase positive cells assumed to be neutrophils that accumulate in the area immediately adjacent to the infected tissue. This process occurs earlier in T. spiralis than in T. sp.3. The timing of the arrival of these cells is suggestive of a previously undescribed role in nurse cell formation. As expected, T. pseudospiralis did not generate a large inflammatory response. This fact along with the lack of nurse cell formation during infection with this species also suggests neutrophil involvement in nurse cell formation. Finally, we have suggested some possibilities for the current observation as related to recent work, indicating the possibility of a much larger role of the neutrophil in this process than previously noted. 


\section{LITERATURE CITED}

Babior, Bernard M. 1990. Phagocytes and nonneoplastic diseases. In Hematology : A pathophysiological approach, Beth Kaufmann Barry (ed.). Churchill Livingstone Inc., New York. p. 273.

Boenisch, T. 1989. Handbook of immunhistochemical staining methods, Sally J. Naish (ed.). Dako Corporation, Carpenteria, CA., p. 9-23.

Boev. S. N., V. A. Britov, and I. V. Orlov. 1979. Species composition of trichinellae. In Trichinella and Trichinosis, William C. Campbell (ed.). Plenum Press, New York and London. p. 40-60.

Bruschi, F., E. Pozio, G. Carulli, R. Polidori, and A. Azzara. 1990. Inhibition of leukocyte function by serum from patients with trichinellosis. Journal of Parisitology 76 : 577-578.

Chadee, K., T. A. Dick, and G. M. Faubert. 1983. Sensitivity of Trichinella sp. isolates to thiabendazole. Canadian Journal of Zoology 61: 139-146.

Dame, J., K. D. Murrel, D. E. Worley, and G. A. Achad. 1987. Trichinella spiralis: Genetic evidence for synanthropic subspecies in sylvatic hosts. Experimental Parasitology 64: 195-203.

Despommier, D.D. 1990. Trichinella spiralis: The worm that would be virus. Parisitology Today 6: 193-196.

Dick, T.A., and K. Chadee. 1981. Biological characterization of some North American isolates of Trichinella spiralis. In ICT5 trichinellosis, C.W. Kim, E.J. Ruitenberg, and T.S. Teppema (eds.). Reedbooks, Surrey, England, p.23-27.

Fernandez, H.N., P. M. Henson, A. Otani, and T. E. Hugli. 1978. Chemotactic response to human $\mathrm{C} 3 \mathrm{a}$ and $\mathrm{C} 5 \mathrm{a}$ anaphylatoxins. I. Evaluation of $\mathrm{C} 3 \mathrm{a}$ and $\mathrm{C} 5 \mathrm{a}$ leukotaxis in vitro and under stimulated in vivo conditions. J. Immunology 120:109-115.

Ford Hutchinson, A.W., M.A. Bray, M. V. Doig, M. E. Shipley, and M. J. Smith. 1980. Leukotriene B, a potent chokinetic and aggregation substance released from polymorphonuclear leukocytes. Nature (Lond.) 286: 264-265.

Guesdon, J.L., T. Ternynck, and S. Avremeas. 1979. The use of avidin-biotin interaction in immunoenzymatic techniques. J. Histochem. Cytochem. 27: 1131-1139. 
Hsu, S.M., L. Raine, H. Fanger. 1981. Use of avidin-biotin peroxidase complex (ABC) in immunoperoxidase techniques. J. Histochem. Cytochem. 29: 577-580.

Hynes, R.O. 1992. Integrins - versatility, modulation and signaling in cell adhesion. Cell 69: 11 .

Klebanoff, S.J. 1971. Intraleukocytic micobicidal defects. Ann. Rev. Med. 22: 39-62, 1971

Kozar, Z., and M. Kozar. 1965. A comparison of the infectivity and pathogenicity of Trichinella spiralis strains from Poland and Kenya. Journal of Helminthology 39 : 19-34.

Kramer, M., G. L. Stewart, and L. Charniga. 1981. A comparative study of Trichinella spiralis (Owen, 1835) and Trichinella pseudospiralis (Garakavi, 1972). Journal of Parisitology 67: 911-916.

La Rosa, G., E. Pozio, P. Rossi, and K. D. Murrell.. 1992. Allozyme anlalysis of Trichinella isolates from various host species and geographical regions. Journal of Parisitology 78: 641-646.

Larsen, E., G. L. Stewart, and J.Y. Niederkorn. 1991. Trichinella pseudospiralis overcomes innate resistance of the Chinese hamster to Trichinella spiralis. Parisitology 103: 465-470.

Leiby, D. A., and W. J. Bacha. 1987. A comparison of three goegraphical isolates of Trichinella spiralis from the midatlantic United States. Journal of Parisitology 73: 207-213.

McRipley, R.J. and A.J. Sbarra. 1967. Role of the phagocyte in host-parasite interaction. XII. Hydrogen peroxide-myeloperoxidase bacterial system in the phagocyte. J. Bacteriol. 94: 1425-1430.

Murrell, K. D., D. A. Leiby, C. Duffy, and G. A. Schad. 1985. Susceptability of domestic swine to wild animal isolates of Trichinella spiralis. In ICT6 trichinellosis, C.W. Kim (ed.). The State University of New York Press, Albany, p. 301-305.

Naccache, P.H., N. Jean, N.W. Liao, J.M. Bator, S.R. McColl, and P. Kubes. 1994. Regulation of stimulated integrin surface expression in human neutrophils by tyrosine phosphorylation. Blood. 84: 616-624.

Pozio, E., G. La Rosa, P. Rossi, and R. Fico. 1989. Survival of Trichinella muscle larvae in frozen wolf tissue in Italy. Journal of Parisitology 75: 472-473. 
Pozio, E., G. La Rosa, P. Rossi, and K. D. Murrell. 1992. Biological characterization of Trichinella isolates from various hosts species and geographical regions. Journal of Parisitology 78: 647-653.

Pozio, E., G. La Rosa, P. Rossi, K. D. Murrell, and J. R. Lichtenfeis. 1992. Taxonomic revision of the genus Trichinella. Journal of Parisitology 78: 654-659.

Smith, J.W., and G.A. Castro. 1978. Relation of peroxidase activity in gut mucosa to inflammation. Am. J. of Physiol. 234: R72-R79

Stewart, G.L., L. Charniga, and R.B. Boley. 1982. Myositis in mouse trichinellosis. Journal of Parisitology 68(4): 730-732.

Stewart, G.L. and E. Larsen. 1989. Infection of the Chinese hamster with Trichinella pseudospiralis. Journal of Parisitology. 75: 1006-7

Svet-Moldovsky, G.J., G.S. Shaghijan, I.Y. Chernyakhovskaya, D.M. Mkheidze, T.A. Litovchenko, N.N. Ozertskovskaya, and Z.G. Kadaghidze. 1970. Inhibition of skin allograft rejection in Trichinella infected mice. Transplantation 9: 69-71.

Ubeira, F. M., J. Leiro, and M. L. Sanmartin-Duran. 1987. Modulation of the antiphosphorylcholine immune response during Trichinella spiralis infection in mice. Parisitiology 95: 583-592. 